The submitted version of the paper published in Experimental Agriculture (2001). Nixon, D.J., Burgess, P.J., Sanga, B.N.K. and Carr, M.K.V. (2001). A comparison of the responses of mature and young tea to drought. Experimental Agriculture, volume 37(3), 391-402.

\title{
A COMPARISON OF THE RESPONSES OF MATURE AND YOUNG CLONAL TEA TO DROUGHT
}

\author{
By D.J. NIXON ${ }^{1,3}$, P.J. BURGESS ${ }^{1}$, B.N.K. SANGA ${ }^{2}$ and M.K.V. CARR ${ }^{1,2,4}$ \\ ${ }^{1}$ International Centre for Plantation Studies, Cranfield University, Silsoe, \\ Bedfordshire, MK45 4DT, UK. (Since 2006: School of Applied Sciences, Cranfield \\ University, Cranfield, Bedfordshire, MK43 OAL, UK) \\ ${ }^{2}$ Tea Research Institute of Tanzania, P.O. Box 2177, Dar es Salaam, Tanzania.
}

\begin{abstract}
SUMMARY
To assist commercial producers with optimising the use of irrigation water, the responses to drought of mature and young tea crops (22 and 5 years after field planting respectively) were compared using data from two adjacent long-term irrigation experiments in Southern Tanzania. Providing the maximum potential soil water deficit was below about $400-500 \mathrm{~mm}$ for mature, and 200-250 mm for young plants (clone 6/8), annual yields of dry tea from rainfed or partially irrigated crops were similar to those from the corresponding well-watered crops. At deficits greater than this, annual yields declined rapidly in young tea (up to $22 \mathrm{~kg}$ $\left(\right.$ ha $\mathrm{mm}^{-1}$ ) but relatively slowly in mature tea (up to $6.5 \mathrm{~kg}$ (ha mm) ${ }^{-1}$ ). This apparent insensitivity of the mature crop to drought was due principally to compensation that occurred during the rains for yield lost in the dry season. Differences in dry matter distribution and shoot to root ratios contributed to these contrasting responses. Thus, the total above ground dry mass of well-irrigated, mature plants was about twice that for young plants. Similarly, the total mass of structural roots ( $>1 \mathrm{~mm}$ diameter), to $3 \mathrm{~m}$ depth, was four times greater in the mature crop than in the young crop and, for fine roots $(<1 \mathrm{~mm}$ diameter), eight times greater. The corresponding shoot to root ratios (dry mass) were about 1:1 and 2:1 respectively. In addition, each unit area of leaf in the canopy of a mature plant had six times more fine roots (by weight) available to extract and supply water than did a young plant. Despite the logistical benefits resulting from more even crop distribution during the year when crops are fully irrigated, producers currently prefer to save water and energy costs by allowing a substantial soil water deficit to develop prior to the start of the rains, up to 250 $\mathrm{mm}$ in mature tea, knowing that yield compensation will occur later.
\end{abstract}

1 Email: P.Burgess@cranfield.ac.uk

3. Present address: Tea Research Foundation (Central Africa), PO Box 51, Mulanje, Malawi.

Email: d.nixon@Africa-Online.net

4. Present address: Crop and Water Management Systems (International) Ltd, Pear Tree Cottage, Frog Lane, Ilmington, Shipston-on-Stour, Warwickshire, CV36 4LG, UK. Email: mikecarr.rtcs@freeUK.com 


\section{INTRODUCTION}

The irrigation of commercial tea (Camellia sinensis) estates in the Mufindi district of the Southern Highlands of Tanzania was initiated in the 1970s, following the demonstration of the yield and other advantages to be gained by applying water during the annual six months of dry weather (Carr, 1974). Currently about 3000 ha of mature tea are being irrigated in Mufindi. Following intensification of management, annual commercial yields of processed tea from the mainly mature, seedling plants are now averaging about $4 \mathrm{t} \mathrm{ha}^{-1}$, whilst the best fields of clonal tea exceed $6 \mathrm{t} \mathrm{ha}^{-1}$. By comparison, average yields in Mufindi from the same seedling tea plants in the 1960s were only about $1 \mathrm{t} \mathrm{ha}^{-1}$ (Carr, 1999). In addition, about 1200 ha of clonal tea have been planted, since 1990, on two new irrigated estates in Southern Tanzania. Both are in areas that are drier than the traditional tea growing districts. Large yields of quality tea must be obtained if these developments are to be profitable. In both situations the water resources available for irrigation are limited and pumping costs are high. Producers are therefore keen to maximise the productivity of the water that is available.

To utilise scarce water resources efficiently it is important to know where the greatest benefits to irrigation water application can be obtained. In this paper the yield responses to drought and irrigation of mature and young clonal tea over an annual period are compared. Based on observations of dry matter partitioning and root distribution with depth, possible reasons for the observed differences are suggested.

\section{METHODOLOGY}

\section{Site and climate}

The Ngwazi Tea Research Station, now part of the new Tea Research Institute of Tanzania, is located in the Mufindi district of Southern Tanzania ( $8^{\circ} 33^{\prime} \mathrm{S}$, $35^{\circ} 10^{\prime} \mathrm{E}$, altitude $1840 \mathrm{~m}$ ). At this site the annual rainfall is typically $800-1100 \mathrm{~mm}$, with a long dry season from May to November. In 1992/93, the reporting period for this study, the rainfall (annual total $1076 \mathrm{~mm}, 1$ June to 31 May) was relatively well distributed throughout the rainy season $(>100 \mathrm{~mm}$ per month from November 1992 to April 1993 inclusive). Evaporation rates ( $E_{\text {pan }}$, see below) averaged about $3 \mathrm{~mm} \mathrm{~d}^{-}$ ${ }^{1}$ during the main growing season (December-May) and the winter months (JuneAugust), increasing to about $5 \mathrm{~mm} \mathrm{~d}^{-1}$ during the warm dry season (SeptemberNovember). The total $E_{\text {pan }}$ for the same 12 month period was $1125 \mathrm{~mm}$. Mean temperatures ranged from $13-16^{\circ} \mathrm{C}$ during the cool dry season (June to August) to 16$19^{\circ} \mathrm{C}$ during the rest of the year. The highest mid-afternoon vapour pressure deficits (about $1.5 \mathrm{kPa}$ ) occurred towards the end of the dry season, whilst the mean daily receipt of short-wave solar radiation varied from $14 \mathrm{MJ} \mathrm{m}^{-2}$ in July to $24 \mathrm{MJ} \mathrm{m}^{-2}$ in October.

The soils at the site are Xanthic ferralsols, with a $0.15 \mathrm{~m}$ deep layer of sandy clay topsoil overlying a deep ( $>5 \mathrm{~m}$ ), freely draining clay subsoil. The $\mathrm{pH}$ is $4.7-5.2$, and the available water capacity (at potentials between -10 and $-1500 \mathrm{kPa}$ ) varies 
with depth from about $140 \mathrm{~mm} \mathrm{~m}^{-1}$ in the top $0.5 \mathrm{~m}$ to $90 \mathrm{~mm} \mathrm{~m}^{-1}$ below $2 \mathrm{~m}$ depth. The soil contains about $330 \mathrm{~mm}$ of extractable water within the $5.5 \mathrm{~m}$ deep rooting zone of mature tea (Stephens and Carr, 1991b).

\section{Assessment of drought levels and water requirements}

In East Africa the potential rate of evapotranspiration from a tea crop (ET; mm $\mathrm{d}^{-1}$ ) has been related to Penman's estimate of open water evaporation $\left(E_{0}\right)$, as modified by McCulloch (1965). The corresponding crop factor (Kc) for healthy well-watered tea with full crop cover is generally accepted to have a value of 0.85 (Laycock, 1964; Dagg, 1970). Daily evaporation from a screened $1.85 \mathrm{~m}$ square $\mathrm{x}$ $0.6 \mathrm{~m}$ deep sunken evaporation pan $\left(\mathrm{E}_{\mathrm{pan}}\right)$ matches this estimate closely under the conditions at Ngwazi (Stephens and Carr, 1991b).

The estimated potential soil water deficit (SWD) on day i can be calculated using a simple soil water balance:

$$
\mathrm{SWD}_{\mathrm{i}}=\mathrm{SWD}_{(\mathrm{i}-1)}+\mathrm{ET}_{\mathrm{i}}+\mathrm{D}_{\mathrm{i}}-\mathrm{R}_{\mathrm{i}}-\mathrm{I}_{\mathrm{i}}
$$

where $\mathrm{ET}_{\mathrm{i}}$ is the crop evapotranspiration, $\mathrm{D}_{\mathrm{i}}$ is the instantaneous drainage, $\mathrm{R}_{\mathrm{i}}$ is the rainfall and $\mathrm{I}_{\mathrm{i}}$ is the irrigation, all calculated daily in $\mathrm{mm}$. Any rainfall or irrigation received when the soil is at field capacity (SWD =0) is assumed to drain instantaneously through the profile.

Early studies indicated that the limiting potential soil water deficit for annual yields from eight to eleven year old, heterogeneous seedling tea plants was about 150 $\mathrm{mm}$, although dry season yields were restricted at deficits less than this (Carr, 1974). More recently, the limiting deficit for dry season yields from mature clone 6/8 plants has been shown to vary from 20 to $300 \mathrm{~mm}$ (average about $40 \mathrm{~mm}$ ), depending on the proportion of fast to slow growing shoots in the population at a particular time (Stephens and Carr, 1989). By comparison, the corresponding limiting value for transpiration was about 60-70 mm (Stephens and Carr, 1991b). For annual yields from mature plants of the same clone, the limiting soil water deficit is about $250 \mathrm{~mm}$ (Nixon, 1995). By contrast the annual yields of the same clone, two and three years after field planting, were reduced beyond actual soil water deficits of $70 \mathrm{~mm}$ and 90 $\mathrm{mm}$ respectively (Burgess and Carr, 1996a). The limiting deficit for yield is clearly dependent on the age of the plant. All these experiments were conducted at the same site in Southern Tanzania.

\section{Experimental details}

The responses to drought of mature and young clone 6/8 crops in the same adjacent field experiments at Ngwazi were compared for the period 1 June 1992 to 31 May 1993. This period was chosen as both the mature and young tea crops had full crop cover, and neither had recently been pruned. By relating annual yields to the maximum potential soil water deficits, the effects of drought on the two crops were compared. Both experiments have been described before and only the essential details are given below.

Experiment 1: this irrigation $\mathrm{x}$ fertilizer experiment (labelled N9) was initiated in 1986 (Stephens and Carr, 1991a). Since planting in 1971, at a rectangular spacing of 
$0.9 \times 1.2 \mathrm{~m}$, the tea had been under commercial management, with partial irrigation. A line-source design (Hanks et al., 1976) was used to give a range of water treatments from fully irrigated to rainfed. Analysis of covariance (using distance from the source as the covariate) was used to remove the effect of any possible linear fertility trend across the experimental site (Morgan and Carr, 1988). The main (fertilizer) plots (21.6 x $5.4 \mathrm{~m}$, containing 108 bushes, replicated four times) were divided into five 3.6 x 5.4 m irrigation sub-plots, each with 18 bushes, on either side of a centrally placed sprinkler lateral. The simple soil water balance model (equation 1) was used to calculate daily potential SWD and to schedule irrigation. About 55 $\mathrm{mm}$ of water was applied to the fully irrigated plots whenever the potential SWD reached $50 \mathrm{~mm}$; the amount of water received by each irrigation treatment was measured using catch cans placed systematically across the experiment. The potential SWD therefore increased through the dry season in all but the fully irrigated treatments, with a maximum potential SWD (SWD $\mathrm{MAX}_{\text {) }}$ of $710 \mathrm{~mm}$ being attained towards the end of the 1992 dry season.

From 1988, the main plot fertilizer treatments ranged from 0 to $450 \mathrm{~kg} \mathrm{~N} \mathrm{ha}^{-1}$ applied annually as a N:P:K 2:1:1 compound. For the purposes of this comparison, only data from the plots receiving annual applications of $300 \mathrm{~kg} \mathrm{~N} \mathrm{ha}^{-1}$ were used, close to current recommended commercial practice. Applications were split, with equal amounts being applied in January and July, except for the unirrigated plots. These received all the fertilizer at the onset of the rains in January. The crop had last been pruned (at a height of $0.4 \mathrm{~m}$ ) in November 1990, and the results reported are therefore from the second year after pruning, 22 years after field planting.

Experiment 2: this clone $\mathrm{x}$ drought experiment (labelled N10) was field planted in August 1988 with six clones of commercial and/or scientific interest at spacings of $0.8 \times 1.2 \mathrm{~m}$, again in a line-source design (Burgess and Carr, 1996a). For the purposes of this study, only yield data for clone 6/8 are used. Between April and October 1989 the plants were brought into production by 'pegging' the lateral stems. The main (clonal) plots were divided into six contiguous drought treatment sub-plots (3.6 x $4.8 \mathrm{~m}$, each containing 18 plants). However in 1992, the central two plots were divided into three plots of $2.4 \times 4.8 \mathrm{~m}$ (12 plants) in order to increase the precision of data recording in that part of the experiment where the rate of water application changed most rapidly with distance from the line source. The amounts of irrigation received by both the two wettest and two driest plots were similar, and so the results from each of these two pairs of plots were combined. During the period of crop establishment the experiment was irrigated uniformly to minimise plant deaths. Differential irrigation was applied for a limited period in the second, third and fourth years after planting. In the fifth year (1992/93, the period being reported), uniform irrigation was applied from the end of the rains (on 2 April 1992) until 19 August. Thereafter differential irrigation treatments were imposed until 16 November when the rains began. The highest $S_{W D} D_{M A x}$ reached in the partially irrigated plots was $420 \mathrm{~mm}$. Irrigation was scheduled and monitored in the same ways as for experiment 1 . Similarly, $300 \mathrm{~kg} \mathrm{~N}^{-1}$ was applied annually as a 2:1:1 compound. These plants had not been pruned since planting. 
In both experiments, the crop was manually harvested at time intervals that were equivalent to two phyllochrons, as estimated from measurements of air temperature (Burgess and Carr, 1998). The aim was to remove all actively growing shoots with two or more fully unfurled leaves, and soft dormant shoots, extending above the established crop surface. The weights of the freshly harvested leaves were converted to dry weights using factors derived from a regression analysis of the leaf dry matter content with the mean air temperature over the preceding two months (Burgess, 1992).

\section{Whole plant harvests}

In order to compare dry matter partitioning in the mature and young tea bushes, whole plant harvests were conducted in the following year (1994). In February, three fully irrigated, mature clone 6/8 plants were destructively harvested from a main plot of experiment 1. Similarly in May, three equivalent, young plants were harvested from an observation plot adjacent to experiment 2. In both cases, the canopy of each plant was separated into leaves, green and woody stems. The dry weight of each component was calculated by multiplying the total fresh weight by the dry matter content determined from three sub-samples that were oven dried at $85^{\circ} \mathrm{C}$ for 48 hours.

\section{Root distribution}

The weights of structural ( $>1 \mathrm{~mm}$ diameter) and fine ( $<1 \mathrm{~mm}$ diameter) roots, within the cross-sectional areas occupied by each harvested plant $(0.9 \times 1.2 \mathrm{~m}$ and $0.8 \times 1.2 \mathrm{~m}$ for experiments 1 and 2 respectively), were measured at $0.2 \mathrm{~m}$ depth increments down the soil profile to $2 \mathrm{~m}$. The roots were washed from the soil and separated into structural and fine categories using callipers. The two sets of roots were weighed, oven dried at $85^{\circ} \mathrm{C}$ for 48 hours, and then re-weighed. The fresh and dry weights of roots were also measured from a full cross-section for one plant, and from a quarter cross-section for two plants, at $0.2 \mathrm{~m}$ depth increments from 2 to $3 \mathrm{~m}$. Although roots of both crops extended to below $3 \mathrm{~m}$, sampling was restricted to this depth because of practical and cost considerations.

\section{Annual yields}

\section{RESULTS}

The fully irrigated mature crop yielded $5900 \mathrm{~kg} \mathrm{ha}^{-1}$ of dry tea (Fig. 1), declining to $3900 \mathrm{~kg} \mathrm{ha}^{-1}$ when unirrigated $\left(\mathrm{SWD}_{\mathrm{MAX}}=710 \mathrm{~mm}\right.$ ). The response to drought was curvilinear. At a deficit of $100 \mathrm{~mm}$, the yield loss per unit of water was only about $0.3 \mathrm{~kg}$ (ha mm$)^{-1}$, increasing slowly to $1.0 \mathrm{~kg}$ (ha mm) ${ }^{-1}$ at a deficit of $300 \mathrm{~mm}$, and then more rapidly to $6.5 \mathrm{~kg}$ (ha mm) ${ }^{-1}$ at a $600 \mathrm{~mm}$ deficit.

In the young crop, the effects of drought on the annual yields were more marked, declining by more than half from $4720 \mathrm{~kg} \mathrm{ha}^{-1}$ under full irrigation to $1960 \mathrm{~kg} \mathrm{ha}^{-1}$ at a SWD MAX $_{\text {of }} 420 \mathrm{~mm}$ (Fig. 1). The yield losses per unit of water increased from 1.8 to 4.2 to $22.0 \mathrm{~kg}$ (ha mm) ${ }^{-1}$ as the $S_{W D}$ MAX reached 100, 200 and $400 \mathrm{~mm}$ respectively. 


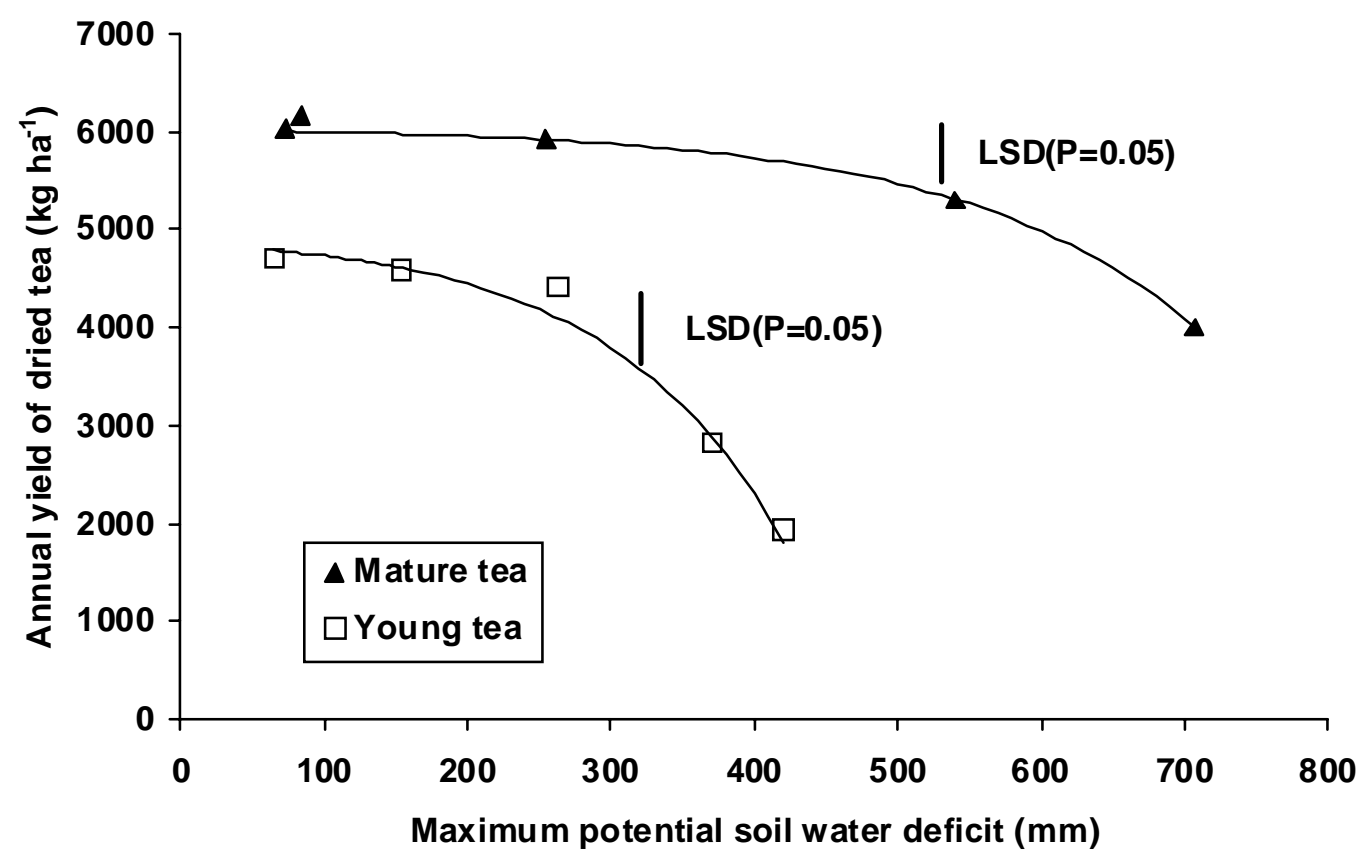

Fig. 1. Relationships between the annual yield of dried tea (1 June 1992 to 31 May 1993) and the maximum potential soil water deficit for mature (22 year-old) and young (five year-old) clone 6/8 plants receiving $300 \mathrm{~kg} \mathrm{~N}^{-1}$ annually ( $\left.\mathrm{n}=4\right)$. The functions for the fitted lines are: mature tea $\mathrm{Y}=$ 6047 - 27.4(1.006119 $\left.{ }^{\text {SWDmax }}\right)$; young tea $\mathrm{Y}=4956-97\left(1.00831^{\text {SWDmax }}\right)$ where $\mathrm{Y}=$ annual yield of dried tea $\left(\mathrm{kg} \mathrm{ha}^{-1}\right)$ and $\mathrm{SWD}_{\mathrm{MAX}}=$ maximum potential soil water deficit $(\mathrm{mm})$.

\section{Seasonal yield distributions}

A major effect of drought (as defined by the progressively increasing values of the $\mathrm{SWD}_{\mathrm{MAX}}$ ) on the seasonal yield pattern of both the mature and young tea crops was to reduce the magnitude of the September/October (dry season) yield peak, which followed the rise in temperatures (Fig. 2). During the remainder of the dry season, by the end of which the SWD $\mathrm{MAX}_{\text {exceeded }} 350 \mathrm{~mm}$ in the young crop, and $700 \mathrm{~mm}$ in the mature crop, yields were uniformly low. Following the onset of the rains (in mid-November), the unirrigated mature tea crop showed large yield peaks in December/January and February/March which exceeded those recorded in the previously irrigated crops (Fig. 2a). The December/January peak was equivalent in size to that produced by the fully irrigated tea in the previous September/October, reaching the equivalent of $350 \mathrm{~kg} \mathrm{ha}^{-1}$ week $^{-1}$. The corresponding yield peaks produced by the young droughted plants after the start of the rains were similar to those from the fully irrigated crop (Fig. 2b), and there was no yield compensation.

Seasonal yield totals are summarised in Table 1 . For mature tea, progressively

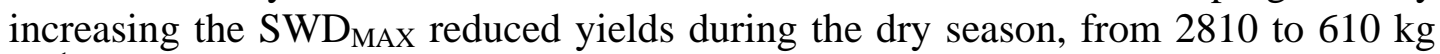
$\mathrm{ha}^{-1}$. However, as a result of compensation, the droughted tea, subjected to a SWD $_{\text {MAX }}$ of $540 \mathrm{~mm}$, yielded up to $21 \%$ more during the wet season than the fully irrigated crop, 3750 and $3090 \mathrm{~kg} \mathrm{ha}^{-1}$ respectively. By contrast, the effect of a SWD $_{\text {MAX }}$ of $420 \mathrm{~mm}$ on the young crop was to reduce both dry season, from 2090 to 
$600 \mathrm{~kg} \mathrm{ha}^{-1}$, and wet season yields, from 2620 to $1360 \mathrm{~kg} \mathrm{ha}^{-1}$. This resulted in greater absolute and relative annual yield losses, at equivalent $\mathrm{SWD}_{\mathrm{MAX}}$ values, compared with the mature crop.

(a) Mature tea

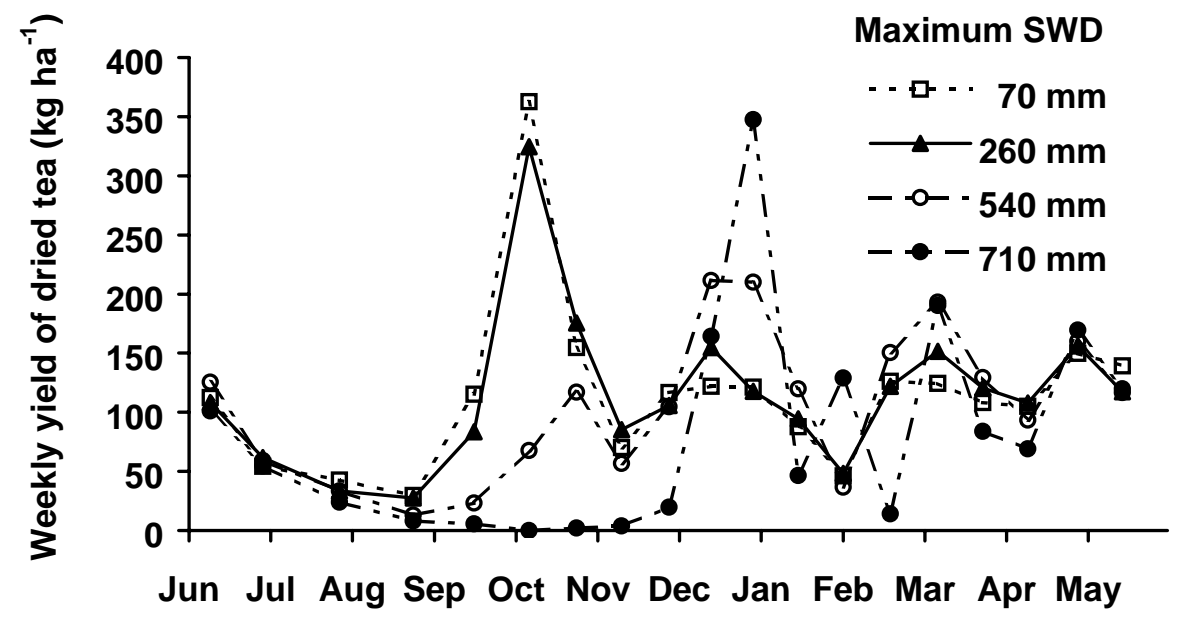

(b) Young tea

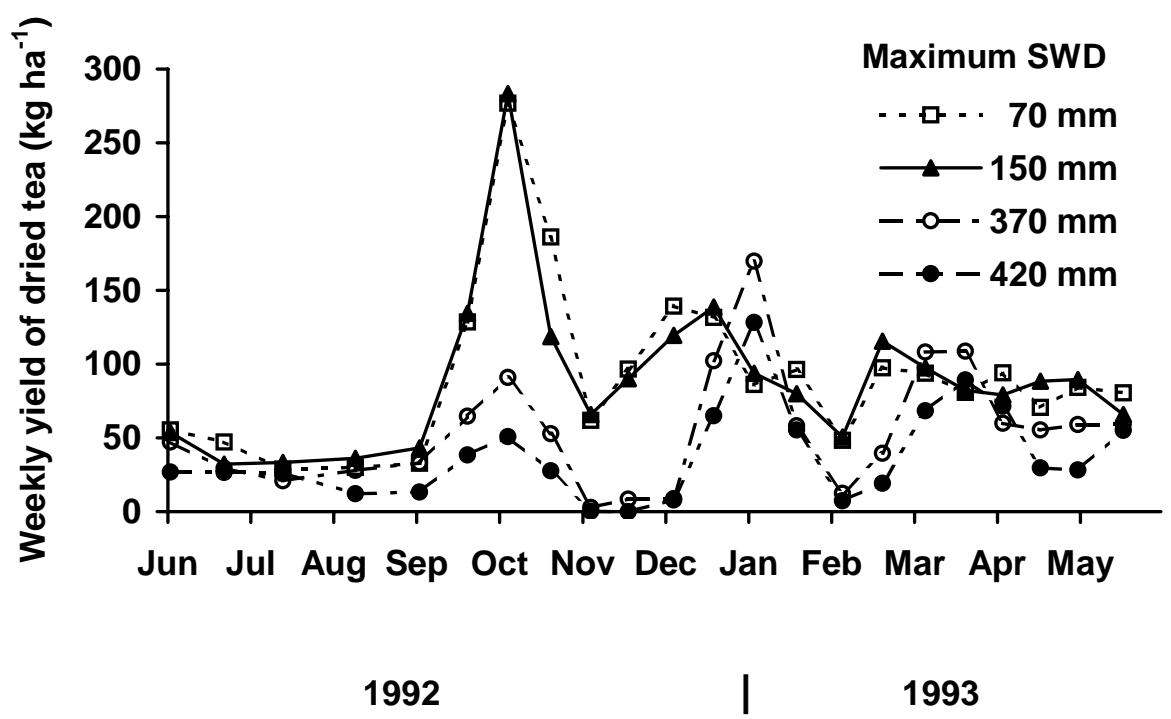

Fig. 2. Weekly yield distribution of (a) mature (22 year-old) and (b) young (five year-old) clone 6/8, each at four levels of maximum potential soil water deficit for the period 1 June 1992 to 31 May 1993 $(n=4)$.

Table 1. The effects of four levels of drought, indicated by the maximum potential soil water deficit $(\mathrm{mm})$, on the yield of dried tea $\left(\mathrm{t} \mathrm{ha}^{-1}\right)$, from (a) mature (22 year-old) and (b) young (five year-old) clone 6/8 obtained during the dry season (1 June to 15 November 1992), the wet season (16 November 1992 to 31 May 1993) and the complete year (1 June 1992 to 31 May 1993). The 
proportions of yield (\%) obtained from the droughted crops, as compared to the well-watered crops $\left(\mathrm{SWD}_{\mathrm{MAX}}=70 \mathrm{~mm}\right)$, are indicated in brackets. The standard errors of difference (sed) between the mean yields within a row are shown in the final column $(\mathrm{df}=11)$.

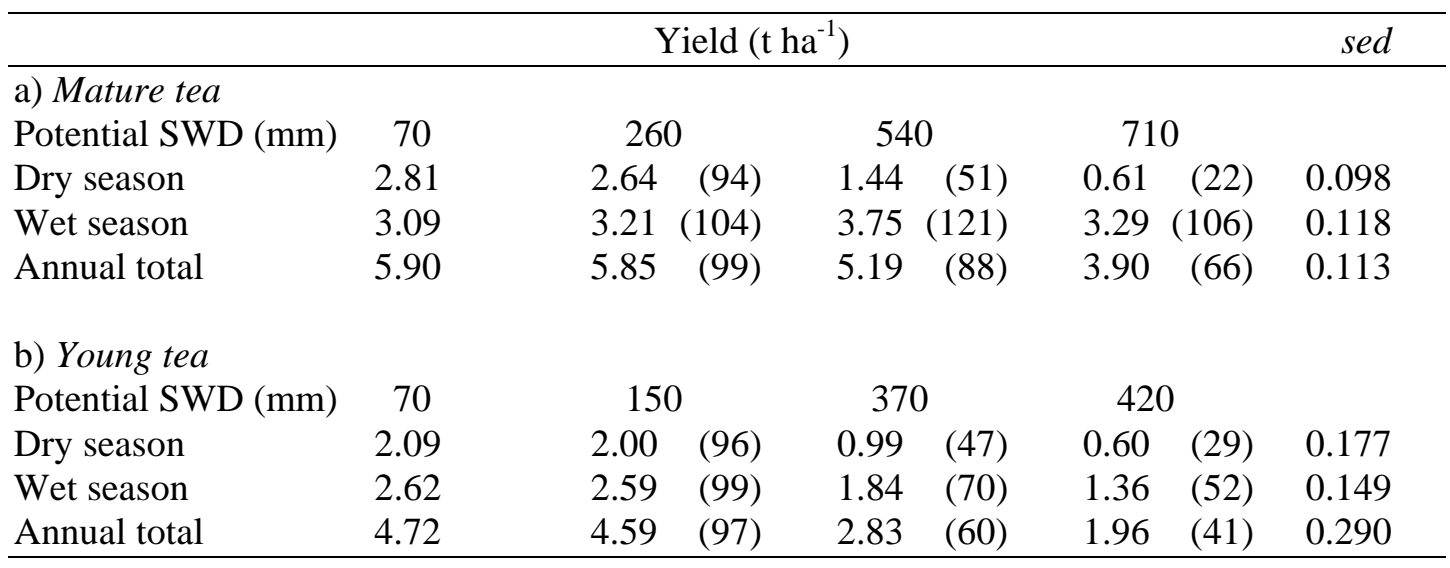

\section{Whole plant harvests}

The mean dry weight of mature clone $6 / 8$ plants was $14.84 \mathrm{~kg}$, of which $7.28 \mathrm{~kg}$ (49\%) were stems and leaves and $7.56 \mathrm{~kg}$ were structural and fine roots (Table 2). By comparison, the mean weight of the corresponding young plants was only 5.66 $\mathrm{kg}$, of which $3.86 \mathrm{~kg}(68 \%)$ were above ground and $1.80 \mathrm{~kg}$ were roots. The shoot to root ratios based on dry weights were therefore about 1:1 and 2:1 for mature and young tea plants respectively.

Table 2. Comparison of the dry weight distribution $(\mathrm{kg})$ in fully irrigated plants of mature and young clone $6 / 8$ harvested twenty-three and six years after field planting respectively $(n=3)$. Standard errors are indicated in parentheses.

\begin{tabular}{|c|c|c|c|c|}
\hline \multirow[b]{2}{*}{ Plant component } & \multicolumn{2}{|l|}{ Mature tea } & \multicolumn{2}{|c|}{ Young tea } \\
\hline & (kg) & $\begin{array}{l}\text { (\% of total } \\
\text { weight) }\end{array}$ & (kg) & $\begin{array}{c}\text { (\% of total } \\
\text { weight) }\end{array}$ \\
\hline Leaves & $0.67 \quad(0.02)$ & 4 & $0.62 \quad(0.04)$ & 11 \\
\hline Green stem & 0.27 (0.04) & 2 & $0.24 \quad(0.02)$ & 4 \\
\hline Woody stem & $6.34(0.36)$ & 43 & $3.00 \quad(0.24)$ & 53 \\
\hline Roots: & & & & \\
\hline Structural (>1 mm diameter) & $5.82(0.10)$ & 39 & $1.56 \quad(0.27)$ & 28 \\
\hline Fine ( $<1 \mathrm{~mm}$ diameter) & 1.74 (0.07) & 12 & $0.24 \quad(0.05)$ & 4 \\
\hline TOTAL & $14.84 \quad(0.36)$ & & $5.66(0.51)$ & \\
\hline
\end{tabular}




\section{Root distribution}

Over $85 \%$ of the structural roots (on a dry weight basis) were to be found in the top $0.4 \mathrm{~m}$ of soil in both mature and young plants, but the absolute weights differed by a factor $>3$ (4.97 and $1.48 \mathrm{~kg}$ plant $^{-1}$ respectively, Fig. 3a). There were similar relative differences to $3 \mathrm{~m}$ depth (5.82 and $1.56 \mathrm{~kg} \mathrm{plant}^{-1}$ ), although this clearly was not the maximum rooting depth in either case. (Clone 6/8 roots have been traced to depths $>5 \mathrm{~m}$ at this site).

(a)

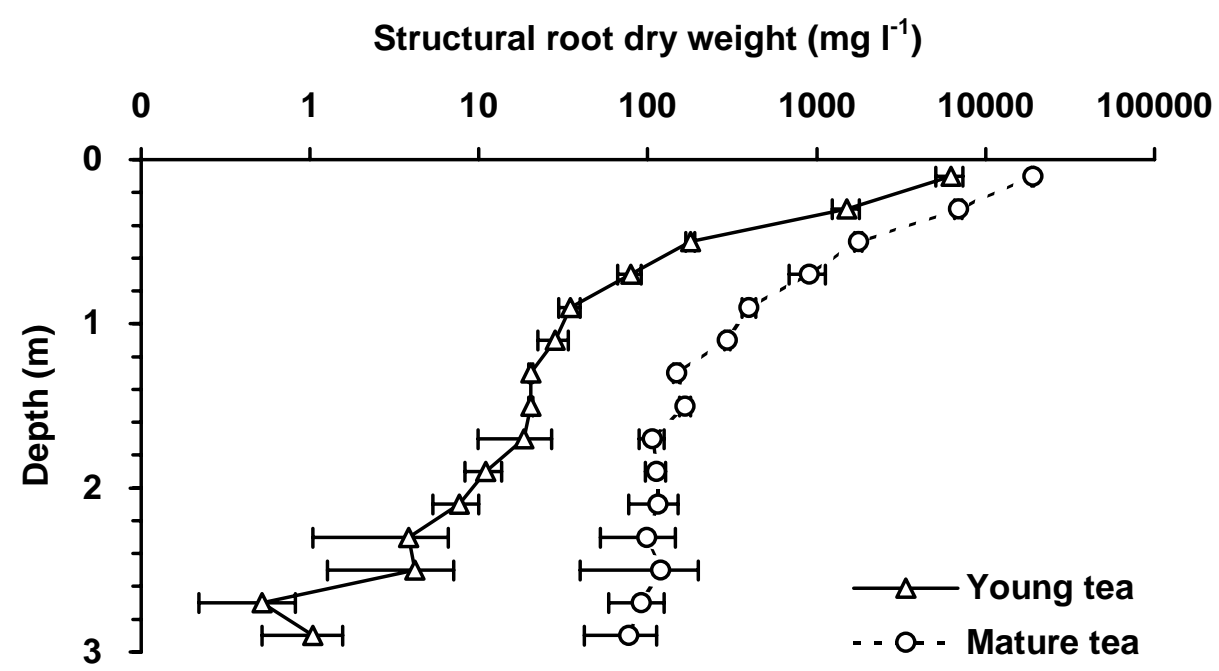

(b)

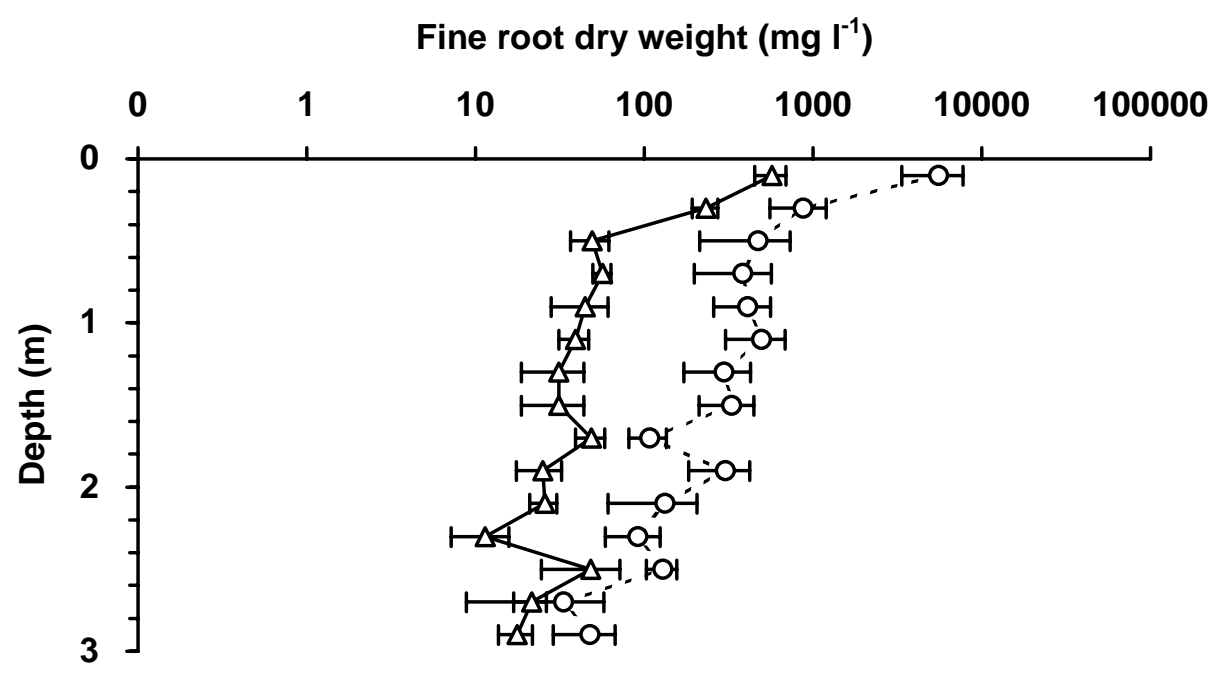

Fig. 3. The mean distribution of (a) structural ( $>1 \mathrm{~mm}$ diameter) and (b) fine ( $<1 \mathrm{~mm}$ diameter) roots for mature (23 year-old) and young (six-year-old) clone 6/8 to a depth of $3.0 \mathrm{~m}$. Standard errors are shown $(\mathrm{n}=3)$. 
In the mature crop, the mean concentration of structural roots decreased rapidly down the soil profile from an average of about $6000 \mathrm{mg} \mathrm{l}^{-1}$ in the top metre of soil to only 170 and $100 \mathrm{mg} \mathrm{l}^{-1}$ at depth increments of $1-2 \mathrm{~m}$ and 2-3 m respectively. By contrast, the corresponding concentrations of structural roots for the young plants over these three depths were only about 1600, 20 and $3 \mathrm{mg} \mathrm{l}^{-1}$ respectively.

The logarithmic profiles of fine root $(<1 \mathrm{~mm}$ diameter) distribution for tea of both ages were more similar in shape to each other than for the structural roots. The total dry weight of these roots, to $3 \mathrm{~m}$ depth, in the mature crop was, however, nearly eight times that of the young crop (1.86 and $0.24 \mathrm{~kg}$ plant ${ }^{-1}$ respectively; Fig. 3b). This is more than twice the corresponding relative difference in structural roots. The concentration of fine roots, at depth increments of $0-1,1-2$ and 2-3 m, were also consistently much greater in the mature crop (averaging about 1500, 300 and $90 \mathrm{mg}$ $\mathrm{l}^{-1}$ respectively) than in the young crop $\left(90,40\right.$ and $30 \mathrm{mg} \mathrm{l}^{-1}$ ). The total root concentration for the mature tea to a depth of $0.5 \mathrm{~m}$ averaged about $2000 \mathrm{mg} \mathrm{l}^{-1}$. For comparison this is about five times the value reported by Fordham (1972) for a 14 year-old seedling tea in Malawi.

\section{DISCUSSION}

This study has highlighted the marked differences in the seasonal and annual yield responses to drought of relatively mature and young clone 6/8 tea plants. Both crops could withstand large maximum potential soil water deficits (SWD $\mathrm{MAX}_{\text {) without }}$ significant $(\mathrm{P} \leq 0.05)$ losses in annual yield (Fig. 1). For the mature tea the critical SWD $_{\text {MAX }}$ was probably in the range $400-500 \mathrm{~mm}$, and for young tea $200-250 \mathrm{~mm}$, equivalent to three to four months and six to eight weeks without rain respectively. Once these values were exceeded the rate of yield decline was relatively small for the mature tea but rapid for the young plants.

These results have obvious and important implications for commercial management. The annual yield response of the young tea $\left.(22.0 \mathrm{~kg} \text { (ha } \mathrm{mm})^{-1}\right)$ to irrigation at a $S W D_{\text {MAX }}$ of $400 \mathrm{~mm}$, was more than three-times greater than that (6.5 $\mathrm{kg}(\text { ha } \mathrm{mm})^{-1}$ ) of the mature crop at a SWD $\mathrm{SAX}_{\text {of }} 600 \mathrm{~mm}$. This clearly means that where water, or finance, is scarce then the irrigation of young tea should normally be

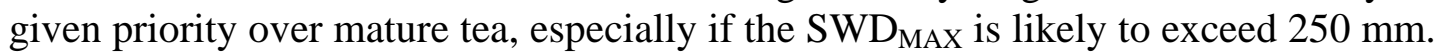
In water response terms, we still need to establish when 'young' tea can be classified as 'mature'.

It is important to emphasise that these responses refer to annual yields. The effects of irrigation/drought on seasonal yield distribution are far more pronounced than this. Evening out crop distribution during the year offers many logistical advantages to managers. Excessively large yield peaks that occur after the start of the rains in rainfed tea are difficult to cope with at harvest, during transport and in the factory. If processing capacity is exceeded, this can lead to leaf being discarded, and certainly to reductions in the quality and value of the manufactured product. For managers, annual yield totals are therefore not the only criteria by which to judge the 
value of irrigation although they are the easiest to quantify in financial terms. Given the constraints on water supplies for irrigation, and its cost, the currently recommended practice for mature tea is to allow a $200-250 \mathrm{~mm} \mathrm{SWD}_{\mathrm{MAX}}$ to be carried forward from the dry season into the rains. In Southern Tanzania, the concept of a SWD $\mathrm{MAX}_{\mathrm{X}}$ has also become a useful management and research tool for scheduling irrigation, and for prioritising water allocation. For tea that has complete ground cover, it can be relatively easily calculated from evaporation pan and rainfall data.

The principal factor responsible for the relative insensitivity of annual yields to water stress is the remarkable capacity of a mature tea crop to compensate for yield lost during the dry season by producing additional crop in the rains. The large peak in production that follows the relief of drought is the result of what has become known in Malawi as the 'Fordham effect'. This occurs after a limiting factor, such as drought (or low temperatures) has ended and allowed the accumulated buds of many ages to develop together. This process can be simulated and successfully modelled (Fordham and Palmer-Jones, 1977; Matthews and Stephens, 1998). Once these shoots have been harvested there is then a decline in production until the next generation of shoots has developed. A second but smaller peak, as reported here, then follows. As well as allowing several generations of buds to develop into harvestable shoots at similar times, the relief of water stress can also lead to, temporary, increases in rates of shoot extension and leaf expansion, resulting in larger leaves, compared with previously well watered crops (Carr, 1969). The capacity of the tea crop to mobilise and utilise starch reserves, which are found in the structural roots, when water becomes available enhances the recovery process from drought, especially in mature tea.

The susceptibility of the young tea crop to drought is probably a result, in part at least, of an imbalance between the atmospheric demand for water and the capacity of the roots to take up that water. The weight of fine roots in the mature crop was about seven times that of the young crop. This meant that the ratio of the dry weight of green leaves to that of the fine roots was 2.6:1 for the young crop, but only $0.4: 1$ for the mature crop. In other words, each unit area of leaf in the canopy of a mature plant had six times more root (by weight) available to extract and supply water than for a young plant. The large density of fine roots in the mature tea, extending well below $3 \mathrm{~m}$ depth, would also mean that there was more 'easily available' soil water in the soil profile than there was for the young crop. Rates of cell expansion would therefore probably have been restricted sooner, at smaller soil water deficits, in young rather than mature plants. Drought also encouraged partial defoliation in young plants, reducing crop cover to $80 \%$ by the start of the rains. In the mature crop, although there was some leaf fall, the ground cover was always $>95 \%$.

Very few data have been published on factors influencing the distribution of tea roots. During the first four years after field planting, Burgess and Carr (1996a) reported that the rates of root development with depth of four clones in experiment 2 , including 6/8, averaged $2 \mathrm{~mm} \mathrm{~d}^{-1}$. After two years, roots had reached maximum depths of about $1.7 \mathrm{~m}$, and after four years $3 \mathrm{~m}$. At 27 months, the above- to belowground dry weight ratio, for fully irrigated plants, was about 2:1. This is similar to the value reported here for six year-old plants. 
The results reported and discussed in this paper refer mainly to one clone only. Although clone 6/8 is widely grown in eastern Africa it is not necessarily typical of the genetic diversity that exists within the region. These studies are continuing.

Acknowledgements: At the time that the measurements reported here were made, the Ngwazi Tea Research Station was sponsored by an industrial consortium comprising Brooke Bond Tanzania Ltd., Mufindi Tea Company Ltd. and Tanganyika Wattle Company Ltd. This station is now part of the new industry owned, Tea Research Institute of Tanzania, which is managed by the International Centre for Plantation Studies, Cranfield University, Silsoe, UK. Julio Lugusi and the late Gallus Myinga gave excellent support in the technical aspects of this study.

\section{REFERENCES}

Burgess, P.J. (1992). Responses of Tea Clones to Drought in Southern Tanzania. PhD thesis, Silsoe College (Cranfield Institute of Technology), UK.

Burgess, P.J. \& Carr, M.K.V. (1996a). Responses of young tea (Camellia sinensis) clones to drought and temperature. I. Yield and yield distribution. Experimental Agriculture 32:357-372.

Burgess, P.J. \& Carr, M.K.V. (1996b). Responses of young tea (Camellia sinensis) clones to drought and temperature. II. Dry matter production and partitioning. Experimental Agriculture 32:377-394.

Burgess, P.J. \& Carr, M.K.V. (1998). The use of leaf appearance rates estimated from measurements of air temperature to determine harvest intervals for tea. Experimental Agriculture 34: 207-218.

Carr, M.K.V. (1969). The water requirements of the tea crop. PhD thesis, University of Nottingham, UK.

Carr, M.K.V. (1974). Irrigating seedling tea in Southern Tanzania: effects on total yields, distribution of yield and water use. Journal of Agricultural Science Cambridge 83:363-378.

Carr, M.K.V. (1999). Evaluating the impact of research for development: tea in Tanzania. Experimental Agriculture 35:247-264.

Dagg, M. (1970). A study of the water use of tea in East Africa using a hydraulic lysimeter. Agricultural Meteorology 7:303-320.

Fordham, R. (1972). Observations on the growth of roots and shoots of tea (Camellia sinensis L) in Southern Malawi. Journal of Horticultural Science 47: 221-229. 
Fordham, R. \& Palmer-Jones, R.W. (1977). Simulation of intraseasonal yield fluctuations of tea in Malawi. Experimental Agriculture 13:33-42.

Hanks, R.J., Keller, J., Rasmussen, V.P. \& Wilson, G.D. (1976). Line source sprinkler for continuous variable irrigation-crop production studies. Soil Science Society of America Journal 40:426-429.

Laycock, D.H. (1964). An empirical correlation between weather and yearly tea yields in Malawi. Tropical Agriculture, Trinidad 41:277-291.

Matthews, R.B. \& Stephens, W. (1998). CUPPA-Tea: a simulation model describing seasonal yield variation and potential production in tea. 1. Shoot development and extension. Experimental Agriculture 34: 345-367.

McCulloch, J.S.G. (1965). Tables for the rapid computation of the Penman estimate of evaporation. East African Agricultural and Forestry Journal 30:286-295.

Morgan, D.D.V. \& Carr, M.K.V. (1988). Analysing line source irrigation experiments. Experimental Agriculture 24:169-176.

Nixon, D.J. (1995). Irrigation of tea in Southern Tanzania: a seminar review. Ngwazi Tea Research Unit Quarterly Report 19:2-23.

Stephens, William \& Carr, M.K.V. (1989). A water stress index for tea (Camellia sinensis). Experimental Agriculture 25:545-558.

Stephens, William \& Carr, M.K.V. (1991a). Responses of tea (Camellia sinensis) to irrigation and fertilizer. I. Yield. Experimental Agriculture 27:177-191.

Stephens, William \& Carr, M.K.V. (1991b). Responses of tea (Camellia sinensis) to irrigation and fertilizer. II. Water use. Experimental Agriculture 27:193-210. 